\title{
Automatic Assessment of Materiality
}

Mohamed A. Wahdan 1

Manar S. Hassan ${ }^{2}$

\begin{abstract}
This paper presents how can information technology (IT) in particular knowledge-based system (KBS) be used in auditing especially when the task requires using professional judgments. It concerned with designing, implementing and evaluating a KBS called Materiality EXpert (MEX). MEX can assess planning materiality and performance materiality as professionals act. Knowledge used to build MEX is inducted from literature, international standards on auditing, and experienced auditors using questionnaire as well as unstructured and structured interviews. MEX was evaluated by 34 auditors from different audit firms in Egypt including international audit firms. The evaluation results acquired from experienced auditors in Egypt indicated that MEX successfully executes the task of assessing the level of planning materiality and performance materiality. Moreover, MEX is efficient, effective, and acceptable from auditors for assessing the level of planning materiality and performance materiality.
\end{abstract}

Key words: Planning Materiality; Performance Materiality; Knowledge-based System; and Egypt.

${ }^{1}$ Assistant Professor of Accounting, Faculty of Commerce, Menoufia University

${ }^{2}$ Assistant Lecturer, Faculty of Commerce, Menoufia University 


\section{التقدير الاتوماتيكى للأهمية النسبية}

ملخص البحث

يهدف البحث الى توضيح كيف تستخدم تكنولوجيا المعلومات وخصوصا النظم المؤسسة على المعرفة فى عملية المراجعة وبصفة خاصة عندما نتطلب مهمة المراجعة استخدام الاحكام المهنية. وبهدف البحث الى تصميم وتتفيذ وتقييم نظام مؤسس على المعرفة. هذا النظام صمم لمساعدة المراجع فى تقدير الاهمية النسبية فى مرحلة التخطيط للمراجعة مثلما يفعل المراجعين ذوى الخبرة.

وتم استتباط المعرفة المطلوبة لأداء هذه المهمة من الدراسات السابقة ومن المعايير الدولية للمراجعة ومن المراجعين ذوى الخبرة باستخدام الاستقصاء والمقابلات الثخصية المنظمة وغير المنظمة.

وتم بناء قاعدة المعرفة الخاصة بالنظام المؤسسة على المعرفة، وتم تحويل المعرفة المكتسبة الى خرائط تدفق للمساعدة فى بناء القواعد المنطقية للنظام المقترح، وتم مراجعتها عن طريق عينة من المراجعين ذوى الخبرة. وقامت عينة من عب مراجع ذو خبرة من مكاتب المراجعة المختلفة متضمنة

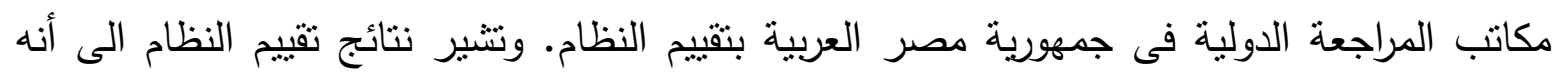
يؤدى مهمة تقدير الاهمية النسبية فى مرحلة التخطيط لعملية المراجعة بنجاح. وأكثر من ذللك فان النظام كفء وفعال ومقبول من المراجعين لتقدير الاهمية النسبية فى مرحلة التخطيط للمراجعة.

الكلمات المفتاحية: تخطيط المراجعة، الاهمية النسبية فى مرحلة تخطيط المراجعة، الاهمية النسبية فى

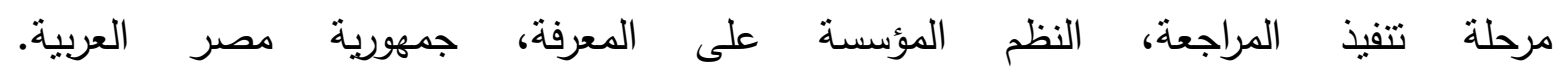




\section{Introduction}

Materiality is one of the most important and argued concepts of auditing. As it concerned with determining what is important to be disclosed or to not be misstated in the financial statements. Companies, financial institutions, public entities and private entities vary in properties, environment and risks (Montoya et al., 2010). In addition, interviews with users of financial statements stated that materiality is misunderstood and its disclosure would only lead to investor misconceptions as to the level of work provided. PWC similarly questioned whether disclosing such information could undermine investor confidence in the audit (Christensen et al., 2018). That's what forced standard's board to determine that the assessment of what's material is the matter of professional judgment and experience of auditors (IFAC, 2009). Professional judgment is a skill that the auditor acquires overtime. Exercising personal judgment may lead to differences in auditor's decision even in materiality. Moreover, it may lead to personal bias or/ misleading audit judgment (Wahdan, 2006). Auditors are in need of systems that can collect all relevant knowledge and experience needed for better assessment of materiality (Russ et al., 2009), and make it available wherever and whenever it is needed to improve audit processes and to determine audit quality (Manita et al., 2011). These systems called knowledge-based system (KBS) or intelligent techniques.

KBS capture tacit knowledge in a very specific and limited domain of a human expertise. These systems capture the knowledge of skilled employees in the form of a set of rules in a software system that can be used by others in the organization. It can provide benefits, help organizations, make highquality decisions with fewer people. Today expert systems are widely used in business in discrete, highly structured decision-making situations (Laudon \& Laudon, 2014).

As materiality is one of the most judgmental areas in auditing (way of their application) and affects all stages of an audit process. Any omission, nondisclosure or misstatement of a material item or fact within a financial statement could affect the decision making of the users. Auditors have to ensure that all material items are included in their testing, evaluation and disclosure in the financial statements. Failure to do so may result in auditor being sued for negligence in discharging their professional duties (Arens et al., 2014).

Assessing materiality in the planning stage will affect the nature, timing and the extent of the audit procedures (Audit Scope). Different assessments of 
materiality in evaluating results stage will affect the auditor's opinion about the financial statements (Azzopardi \& Baldacchino, 2009). Moreover, the concept of materiality is applied in forming an opinion on the financial statements ISA 700 (MIA, 2012). Materiality has been defined by auditing standards. However, the basis of evaluating materiality aren't determined, therefore there is no specific or optimal materiality assessment.

Factors promoting decision aid in formulating the materiality's assessment are: (1) there are some difficulties in passing the expertise to new auditors. (2) Auditors usually use a "personal-judgment" approach; they heavily depend on their own experience and expertise (Curtis \& Hayes, 2002; O'Leary, 2003; Wahdan et al., 2009). This approach may be ineffective and may lead to different auditors coming to different decisions, developing a personal bias, increasing/decreasing audit evidence, and/or giving misleading judgments. (3) Litigation risk faced by the auditor. (4) Time pressure on auditor. And (5) Audit difficulties result from quick change in standards and the tremendous amount of transactions under auditing. Moreover, the way auditors apply and use this concept in practice is one of the most argued subjects. There are no specific rules or prescriptions that can be followed in all circumstances to assess materiality. It is the matter for the auditor to decide whether a particular item has a material impact on the financial statements or not, and auditors usually use a "personal-judgment" approach. So a computerized program for assessing materiality will be very useful. Thus, the main research questions examined in this paper are: (1) how can a knowledge-based system be developed and used for assessing materiality in the audit planning stage? And (2) to what extent is the proposed KBS for assessing planning materiality and performance materiality effective, efficient, and acceptable as an auditing tool and a training tool?

In order to construct, implement, and evaluate a KBS, which is able to assess planning materiality and performance materiality, we must investigate the auditors' relevant knowledge and reasoning method related to the task. In our investigation, a KBS was developed called Materiality EXpert (MEX), which is able to assess planning materiality and performance materiality. MEX contains all knowledge associated with the auditor's assessment on the level of planning materiality and performance materiality. MEX is targeted in particular at the auditing practice in Egypt. This country has only a limited number of experienced auditors who are adequate in assessing the level of planning materiality and performance materiality (Wahdan et al., 2005). To develop MEX, knowledge was acquired from the literature and elicited from an appropriate set of experienced auditors through questionnaires and in-depth interviews. 
MEX is expected to increase auditor's efficiency. According to experts, efficiency is measured by the time required to perform the task, numbers of organizational levels involved in the task, and/or effort needed to achieve this task. Furthermore, MEX is expected to increase auditor's effectiveness. As it leads to a consistent and uniform assessment of planning materiality (PM) and tolerable error (TE) through structured process. Moreover, MEX may be used as internal training tool at auditing firms to build up the experience of the novices using structured knowledge elicited from experts. Despite, the area of how to assess materiality is important to the conduct of an audit, and the foundation from which audit scope decision is made. Previous researches on qualitative measures such as Earnings Before Income Tax and Amortization (EBITA) are limited (CAQ, 2017).

The outline of the paper is as follows. Section 2 presents the literature review. Section 3 introduces research methodology. Section 4 presents the conceptual models of MEX. Section 5 presents the evaluation of MEX, and section 6 illustrates the conclusion and points to future research.

\section{Literature review}

\subsection{Literature related to using KBS}

In 2005, Comunale \& Sexton demonstrated the application of fuzzy logic to assess materiality. The idea is to build an expert system based on fuzzy logic that assesses materiality. The researchers point out that the system differs from most expert systems in a very important way. Most expert systems are designed to emulate the performance of an expert. But this system is designed to improve the performance of the expert.

In 2006, the study of Wahdan explored the current auditing framework and challenges in Egypt, listed the relevant audit assessments required for formulating the auditor's opinion on financial statements in Egypt, construct and modulate the audit assessments in a KBS, called Auditor Report Expert, that is able to formulate the auditor's opinion on financial statements, finally validate and evaluate the effectiveness, efficiency, and acceptance of AREX by conducting test cases and actual cases in Egyptian audit firms. The conclusion of the study stated that AREX structure consists of eight models, which correspond to the eight audit assessments required to formulate the auditor's opinion. AREX is effective in formulating the auditor's opinion and provides an effective user interface and good explanation facility. These facilities may help in training the novices.

In 2012, Devale \& Kulkarni explained the use of expert system in information system audit and how the organizations are moving to a computer-based audit approach that can be adapted to develop and improve 
the continuous audit process. The results of the study stated that computer programs such as expert systems can be used to improve the consistency of human responses and mitigate errors. Utilization of the expert system will lend consistency, accuracy and verifiability to the audit opinion decision process. Moreover, there is feasibility and benefits of applying expert systems methodology to the information system auditing.

In 2012, the study of Gunawan investigated (1) how a Knowledgeintensive System (KIS) may support a user in interpreting the business financial performance and (2) to what extent it is possible to develop a KIS and apply it to the Indonesian SME Garment manufacturers (ISGMs). The findings of the study stated that The ISGMs face two significant business challenges: (1) the lack of qualified information for decision making and (2) the inability to interpret the results of financial statements analysis and key performance indicators. The ISGMs manager needs a support for accessing qualified information. This support may improve the quality of managerial decision making for reaching two key business targets: (1) better productivity and (2) better quality. A combination between two intelligent techniques (AIS and KIS) can be used for mimicking the logic of thinking by both financial experts and garment experts.

In 2013, Bukhsh \& Weigand tried to optimize the audit procedure by using intelligent/smart techniques. Therefore the study question is "how efficiency and effectiveness of audit process can be increased by using smart techniques". The findings suggest that auditing with smart technique provides a massive potential for innovation. Algorithm and framework for smart auditing has been developed. An audit process can be as smart because it reduces the human effort and produces reliable and efficient results.

In 2013, Wahdan attempted to model, implement and validate a knowledge-based system, called the "Auditor's Report on Internal Controls" (ARIC) that is capable of formulating the opinion on the effectiveness of internal controls over financial reporting. To develop ARIC, knowledge was acquired from the literature and elicited from experienced auditors. From the results of the validation, the author concludes that ARIC is successful in performing the task of evaluating the internal controls over financial reporting.

By reviewing the literature, to the best of our knowledge, until now no KBS developed for assessing materiality in the planning stage of the audit process using practical expertise and experience. The current study focuses on designing a KBS able to assess materiality in the planning stage of the audit process. 


\subsection{Literature related to factors affecting materiality assessment}

In 1996, Iskandar \& Iselin discussed the importance of materiality in auditing and accounting, and some of the problems faced by auditors and accountants as a result of the absence of materiality judgment guidelines. They also discussed the resulting risks for users of financial statements. The paper concludes that industry is a contextual variable which forms an important input to materiality judgments. It is expected that industry has been a factor that may have contributed to the inconsistency of materiality judgments in the past study. Thus auditors utilize industry knowledge in making risk assessment and materiality judgments.

Brennan \& Gray (2005) reviewed the literature on materiality in accounting. It starts by examining the context in which materiality is relevant, and the problem arising from applying the concept in practice. In addition, methods of calculating quantitative thresholds are described. The conclusion of the study calls on regulators to extend disclosure requirements to include information about materiality levels to enhance transparency of accounting and auditing. Shareholders and investors are entitled to have this information. They are entitled to be informed about the imprecision underlying what otherwise looks very precise.

In 2009, Azzopardi \& Baldacchino attempted to evaluate the Maltese auditing profession's perceptions and to use the concept of materiality in the performance of an audit as well as attitudes towards disclosure of materiality thresholds. The study found that materiality treatment is inconsistent among practitioners in Malta. They do not treat materiality uniformly, with various materiality thresholds applied in practice. As materiality standards can never cover all possible circumstances, prescriptive guidelines are not advisable. Various difficulties could be resolved by introducing audit software which is available to practitioners.

In 2009, Juma'h presented some concepts of materiality, classification of materiality, qualitative and quantitative measures. The researcher concludes that, in absence of normative guidelines for materiality applications for decision making, qualitative and quantitative methods are used to determine the accounts' position on the materiality of a decision making. Qualitative methods include accountants' own judgments based on their experience and quantitative based on historical data of financial and nonfinancial variables.

In 2009, the study of Park provided a clearer and more rational basis for assessing materiality with respect to financial misstatements. At the outset, it is important to distinguish between financial misstatements, which are the focus of this study, and nonfinancial misstatements. This study's analysis is 
limited to financial misstatements, or misstatements in a company's financial reports. Though the same reasonable investor standard generally governs financial and nonfinancial misstatements, financial misstatements are more susceptible to scrutiny through quantitative benchmarks than nonfinancial misstatements. The conclusion of the study provides an alternative to assess materiality primarily by assessing the market's reaction to the misstatements.

Emil, et al. (2010) aimed at providing a temporal evolution of the undertaken studies in the field of the factors that influence materiality and to highlight the need for regulations that provide professional support to auditors in order to realize a more accurate calculation of materiality. The conclusion of the study outlines these qualitative factors studying 1 - the characteristics of the audited companies (auditee), the most important determinants are: the characteristics of leadership, the financial situation and the internal control quality, the size and the sector (industry) in which the companies operate, changes in the accounting policies and audit committee characteristics. 2Characteristics of the audit firm performing the audit, highlights the following factors of influence: the structure and the size of the audit firm, company's culture and its relationship with customers. 3- The auditor's individual characteristics, we can observe that among the factors of influence are: the auditor's professional characteristics (knowledge, dependence on fees etc.), professional experience, other personal characteristics (age, innate ability, mood, sex etc.).

Houghton, et al. (2011) focused on the issue of materiality judgments and the need for public disclosure of materiality levels. Insights about the concept of materiality are drawn from the words of users of audited financial reports, auditee management, suppliers to the market for audit services, auditing standard setters, and regulators. The study based on face-to-face office interviews with individuals representing identified groups of stakeholders in the market for audit services about the issue of "materiality" as this concept is applied in auditing. The interviews canvassed many issues related to audit as part of a larger project entitled "The future of audit". The study concluded that in general, stakeholders perceive that the concept involved in audit materiality are not well understood and they point to the difficulty in providing educative materiality about it, especially in relation to qualitative materiality, to retail investors. There are mixed views as to whether the actual level of tolerable error should be disclosed with some feeling that it might be dangerous.

In 2011, Manita, et al. studied the influence of qualitative factors (SAB.99) on the ethical judgments of materiality in France. The experimental study was carried out with a sample of 44 experienced auditors, and implies the results of three qualitative factors on materiality's ethical judgments. The results show 
that the majority of auditors consider the qualitative factors influence their ethical judgments of materiality, and the incoherence of the classic approach according to which the net result is the dominating reference criterion to explain the decisions of correction of the anomalies. There are no significant differences if judgment between the auditors of big- 4 and those belonging to small firms concerning the impact of qualitative factors. The results revealed that the criteria of magnitude of consequences and the social consensus of Jones (1991) justify and motive the judgment of auditor better than other criteria.

In 2013, Ndreca shed light on the application of materiality in nature as one of the best techniques that provides assurance in auditing the financial statements. He explains the relationship between materiality and audit risk, the procedures to be followed in determining the assurance factor, and proving that the best efficiency in auditing financial statements can be achieved if we apply materiality in nature. Ndreca also explains the nature of indicators and the method of calculation. The findings of the study indicated that it isn't possible to find all material errors in the financial statements but when auditors applying these techniques, they will be able to see the trend of material misstatements of the financial statements. Furthermore, auditors cannot provide reasonable assurance that the financial statements have no material errors if they determine the number of transactions solely without taking into account the assurance factor.

Prior studies focused on how to assess materiality and if auditors use qualitative or quantitative methods. Some studies focused on one or more of these factors: industry of the firm, characteristic of the audited company, characteristic of the audit firm, user's interest, materiality level of previous years ...etc. The current study takes into account most of these factors that are considered important from the auditors' point of views and elicit knowledge from 30 experienced auditors, in addition, examining its importance from experts (using questionnaire), knowledge base was built and 34 auditors participate in evaluating MEX.

\section{The Research Methodology}

This research investigates how the assessment of materiality may be improved by using a KBS. It focuses on constructing, implementing, and evaluating MEX. To achieve the research goal, a research methodology consisting of 5 phases was developed: 1) reviewing the literature, 2) designing a questionnaire, 3) constructing the proposed KBS based upon practical flowcharts, 4) implementing MEX, and 5) evaluating MEX. Knowledge elicitation is the first step in building an expert system (Sagheb-Tehrani, 
2009). Different ways are applicable to elicit knowledge from experts such as structured interviews, unstructured interviews, documentation analysis, case study analysis, and observation analysis (Sagheb-Tehrani, 2009). During the knowledge elicitation: knowledge problem is identified, and determines if we can use knowledge from experts, textbook and articles (Wahdan, 2006). The study was divided into five steps as follows:

1) A profound literature review was performed for acquiring knowledge to assess planning materiality. In addition to other data sources that are up to date by its nature, such as: academic materials, periodicals, and auditing standards concerning the assessment of materiality

2) The questionnaire (No.1) with in-depth interviews was used to elicit the knowledge from 30 experienced auditors from different audit firms in Egypt, including international audit firms. In order to acquire the auditors' knowledge and expertise needed to assess planning and performance materiality. The questionnaire consists of questions requiring a response on a five-point Likert-scale (always, often, sometimes, rarely, never). Disagreements among auditors are decreased and if there are still disagreements, the main expert takes a decision. Example of the conflicting concept is the confusion occurs between performance materiality, as it is new and not widespread and planning materiality. Performance materiality is an alternative to tolerable error.

3) Our conceptual model structures the assessment of materiality in the audit planning stage. The conceptual model consists of assessing planning materiality and performance materiality. Flowcharts were constructed based upon the knowledge collected and elicited in the previous phases above. The arrows in flowcharts indicate that the output of one of the models is used as input for the other.

4) The knowledge acquisition process was structured according to Extensible Markup Language (XML), using the models specified in the previous step. It is remarked that reasoning systems play an important role in the implementation of artificial intelligence and knowledge-based systems. C\# (C Sharpe) is a programming language that was used to build the reasoning system, which is used to achieve the conditional rule and give the user the advice as per the answers of the questions comes out from MEX.

5) After the auditors had used MEX, they were asked to answer questions formulated in the questionnaire (No. 2) in order to determine its effectiveness, efficiency, and acceptance in assessing materiality in the planning stage of the audit process. A five-point Likert-scale was used in the questionnaire. 


\section{The Conceptual Framework of MEX}

ISA 320 specifics 3 main characteristics of materiality (IFAC, 2009; MIA, 2012):

1- Misstatements are considered material if, individually or in the aggregate, they could reasonably be expected to influence the economic decisions of users based on the financial statements.

2- Judgments about materiality are made in context of surrounding circumstance, and are affected by the size (quantitative - monetary amount involved) and/or nature of misstatements (qualitative).

3- Judgments about materiality are based on consideration of common financial needs of users as a group.

\subsection{Bases or benchmarks in determining materiality}

It is necessary to have bases to determine if the misstatement is material. The decision of choosing benchmark depends on which item of information is critical for users. Therefore, Factors that may be considered in establishing benchmarks include (Ndreca, 2013): (1) Elements of the financial statements that will be of interest to users, (2) Whether user is interested in evaluating financial performance or liquidity, (3) Where the entity is in the life cycle (growing, mature, etc.), and the industry and economic environment in which the entity operates, (4) The entity's ownership structure and the way it is financed. If the entity is financed mostly by debt, users may pay attention on assets and any claims more than on the entity's earnings, and (5) The relative volatility of the benchmark, however, profit before tax from continuing operations is often used for profit-oriented entities, it may fluctuate from year to another, other benchmarks such as gross profit or total revenues may be more appropriate.

According to ISA 320 examples of benchmarks that may be appropriate, depending on the circumstances of the entity (entity's lifecycle, user's interest, entity's ownership structure and volatility of the benchmark) are: profit before tax, total revenues, gross profit and total expenses, total equity or net asset value. Profit before tax from continuing operations is often used for profitoriented entities (IFAC, 2009).

\subsection{Materiality level or threshold}

Materiality level or materiality threshold is a materiality level above which an item is considered material and below which is regarded as immaterial. ISA 320 stated that (IFAC, 2009):

"Determining a percentage to be applied to a chosen benchmark also involves the exercise of professional judgment" 


\subsection{Materiality assessment at audit planning stage}

Auditing standards require auditors to determine the combined amount of misstatement in the financial statements that they consider material and called preliminary judgment about materiality. As it is the maximum amount by which the auditor believes that the financial statements could be misstated and still not affect the decision of reasonable users (Eilifsen \& Messier, 2014). The higher the amount of preliminary judgment, the lower evidence required. Auditors may change this amount according to any change in the factors affecting these judgments or due to qualitative events, such as the issuance of debt that created a new class of financial statements' users. Planning Materiality or overall materiality (PM) is often determined before year-end and is based on prior years' financial statements or annualized interim financial statements information (Arens et al., 2014).

In essence, the materiality measure is subdivided into smaller amounts. This is called performance materiality. The degree of reduction from overall materiality depends on the level of risk associated with the audit, the quality of the internal control environment at the entity (Council, 2017). It is very important in determining the nature, timing and extent of audit procedures because evidence is accumulated by segment rather than for the financial statements as a whole. There is an inverse relationship between performance materiality and the amount of evidence auditor will accumulate.

The one presented in the AICPA'S Audit Sampling Guide 2001 is to apply a percentage between $50-60 \%$ of planning materiality to determine the tolerable misstatements (Chen et al., 2008). Based on interviews in big audit firms in Egypt, they use a percentage of $50-75 \%$ of planning materiality. The starting point for setting performance materiality is $50 \%$ of PM for listed entity and entities in regulated industries, $75 \%$ of PM for non-listed entities in some unregulated industries. But whether deciding to raise performance materiality to $75 \%$ of PM for a listed entity or entities in regulated industry, or to lower TE to $50 \%$ of PM for non-listed entities, the auditor considers: expectation about misstatements, understanding the entity and industry, past history with the entity, assessment of the risks, and the effectiveness of internal control over the financial statements. Most practitioners allocate materiality to balance sheet rather than income statement (Arens et al., 2014).

Based on interviews with auditors and investigation of some documents at one firm of the big-4 in Egypt, we found that performance materiality can vary for different classes of transaction, account balance, and disclosure according to control risk, and the inherent risk. Performance materiality amount is allocated to specific items according to the item's inherent risk and internal control evaluation. 
- If the auditor relies on internal control and higher inherent risk (IR), the TE will be as in Table 1

Table 1: TE for key items when auditor relies on control and higher inherent risk

\begin{tabular}{|c|c|c|}
\hline Rely on Control / Higher IR & For assets / income & For liabilities / expenses \\
\hline Lower range & $\mathbf{5 0 \%}$ of TE & $\mathbf{1 5 \%}$ of TE \\
\hline Higher range & $\mathbf{7 5 \%}$ of TE & $\mathbf{2 5 \%}$ of TE \\
\hline
\end{tabular}

- If the auditors rely on internal control and lower inherent risk, the TE will be as in Table 2

Table 2: TE for key items when auditors rely on control and lower inherent risk

\begin{tabular}{|c|c|c|}
\hline Rely on Control / Lower IR & For assets / income & For liabilities / expenses \\
\hline Lower range & $\mathbf{7 5 \%}$ Of TE & $\mathbf{2 5 \%}$ Of TE \\
\hline Higher range & $\mathbf{1 0 0 \%}$ Of TE & $\mathbf{5 0 \%}$ Of TE \\
\hline
\end{tabular}

- If the auditors cannot rely on internal control and higher inherent risk, the TE will be as in Table 3

Table 3: TE for key items when auditors cannot rely on control and higher inherent risk

\begin{tabular}{|c|c|c|}
\hline Not Rely on Control / Higher IR & For assets / income & For liabilities / expenses \\
\hline Lower range & $\mathbf{1 0 \%}$ Of TE & $\mathbf{5 \%}$ Of TE \\
\hline Higher range & $\mathbf{2 5 \%}$ Of TE & $\mathbf{1 0 \%}$ Of TE \\
\hline
\end{tabular}

- If the auditors cannot rely on control and lower inherent risk, the TE will be as in Table 4

Table 4: TE for key items when auditors cannot rely on internal control and lower inherent risk

\begin{tabular}{|c|c|c|}
\hline Not Rely on Control / Lower IR & For assets / income & For liabilities / expenses \\
\hline Lower range & $\mathbf{2 5 \%}$ Of TE & $\mathbf{1 0 \%}$ Of TE \\
\hline Higher range & $\mathbf{5 0 \%}$ Of TE & $\mathbf{1 5 \%}$ Of TE \\
\hline
\end{tabular}

\subsection{Qualitative and quantitative Factors}

One approach to assess the quantitative materiality supposed from the early studies on materiality is to use a percentage of a key figure in the financial statements. These studies agreed that the size of an item as a percentage of the net profit of the current year is the most important factor influencing decision on materiality (Emil et al., 2010). According to reviewing several studies (Juma'h, 2009; Pany \& Wheeler, 1989; Steinbart, 1987; Vaassen, 1994), one of the most important factors is the client's industry. other factors may include management features and lifestyle, the state of internal control, expected users of financial reports, the financial situation, management accounting policies, and whether the company participates in the stock market or not (Juma'h, 2009; Emil et al., 2010) 
Furthermore, the auditor's individual characteristics such as: the auditor's professional characteristics (knowledge, dependence on fees), professional experience and other personal characteristics (age, innate ability, mood, and sex) considered important factors (Juma'h, 2009; Emil et al., 2010). In addition, characteristics of audit firm in terms of: the structure and size of the audit firm, company's culture and its relationship with customer, may influence.

\subsection{Materiality, Audit Risks and Audit Evidence}

Risk is a measure of uncertainty, whereas materiality is a measure of magnitude or size. Taken together, they measure the uncertainty of amounts of a given magnitude (Eilifsen et al., 2014). Performance materiality does not affect any of the four risks, and the risks have no effect on performance materiality, but together they determine planned audit evidence. The quantity of audit evidence needed is affected by the risk of material misstatements (in the audit of financial statements) or the risk associated with the control (in evaluating the effectiveness of internal control over financial reporting) (PCAOB, 2010; Feng, 2017). Figure 1 illustrates the relationship between performance materiality and risks to planned evidence.

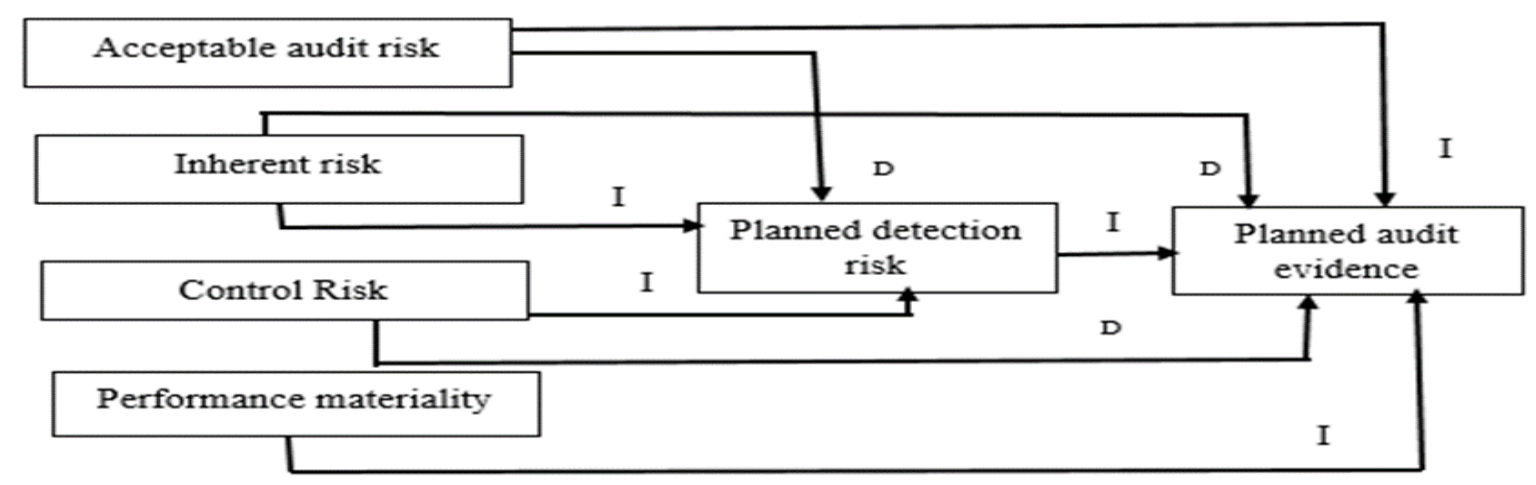

Figure 1: Relationship of performance materiality and risks to planned evidence Source: (Arens et al., 2014)

PCAOB (2010) defines audit evidence as:

"All the information obtained from audit procedures or other sources that is used by the auditor to reach the conclusions about the fairness of the financial statements"

The objective of the auditor is to plan and perform audit to obtain sufficient appropriate audit evidence to provide a reasonable basis for his or her opinion expressed in the auditor's report (PCAOB, 2010).

Sufficient is the measure of the quantity of audit evidence. The quantity of needed audit evidence is affected by the risk of material misstatements (in the audit of financial statements) or the risk associated with the control (in the 
audit of internal control over financial reporting) (PCAOB, 2010). Performance materiality is inversely related to the amount of audit evidence an auditor will accumulate (Arens et al., 2014). Quality of the audit evidence is obtained. As the quality of the audit evidence increase, the need for additional corroborating evidence decreases.

Appropriateness is the measure of the quality of audit evidence (its relevance and reliability). The reliability of evidence depends on the nature and source of the evidence and the circumstances under which it is obtained.

For instance, we have two companies; one of them with low inherent risk and low control risk it means there is a low probability of misstatements ( company B) and the other is a company with high inherent risk and high control risk so the probability of existence of misstatements is high (company A). As we define materiality level as the Egyptian pound level amount where misstatements larger than this amount require adjustment in the FS. Figure 2 demonstrates factors affecting materiality

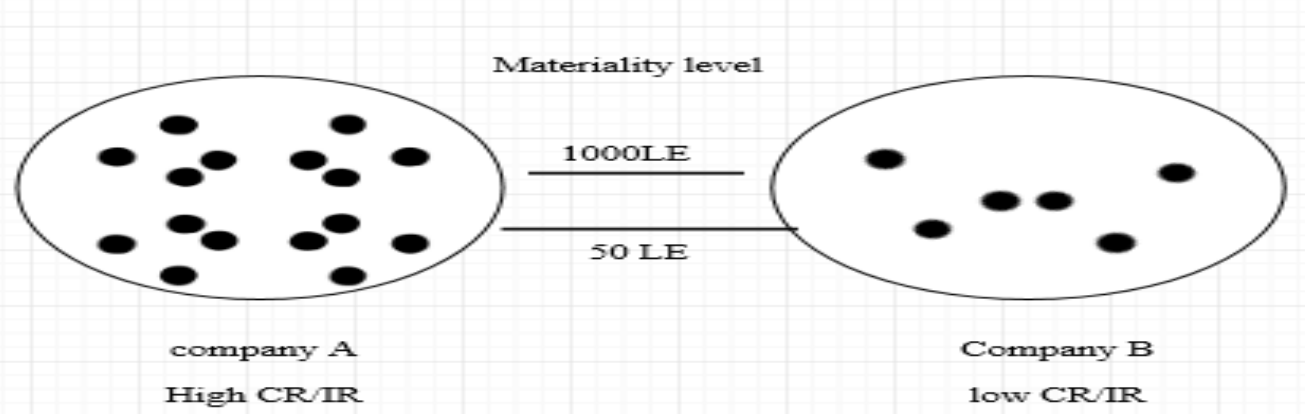

Figure 2: Factors affect level of materiality

There are two level of materiality high and low. If the materiality is stated at the high level for both companies, auditors will consider misstatements above this level are material and this will result in more misstatements in company (A) not be detected and may be material. On the other hand, if the materiality is stated at the lower level. Auditors will express much more effort than needed in company (B) as the actual misstatements aren't common due to the effective internal control and low inherent risk. So materiality and detection risk move in the same direction. Detection risk and inherent / control risk move in opposite directions.

\subsection{The Impact of Materiality on the Auditor's report}

Materiality is addressed for each reporting issue regarding the consistency, scope restriction, and accounting principles (Groomer and Heintz, 1999; Messier, 2000; Gist and Shastri, 2003; Al-Sharairi, 2013). According to Arens 
et al. (2014), the following three levels of materiality affect the type of opinion on the financial statements. Table 5 illustrates the effects of materiality on the type of the auditor's opinion.

1. The amounts are immaterial: if a misstatement is unlikely to affect the decisions of a reasonable user of the financial statements, it is immaterial. Thus, an unqualified opinion will be appropriate.

2. The amounts are slightly material: the amounts are material but do not overshadow the financial statements as a whole. If a misstatement in the financial statements affects slightly the users' decision, but the overall financial statements are fairly presented, a qualified opinion will be appropriate.

3. The amounts are highly material: the amounts are highly material where the fairness of the financial statements, the non-compliance with the accounting principles, the scope restriction, or the going concern is in question. If the highest level of materiality exists, a disclaimer of opinion or an adverse opinion should be expressed, depending on the existing conditions, as shown in Table 5.

Table 5: The effects of materiality on the type of the auditor's opinion

\begin{tabular}{|c|c|c|}
\hline \multirow[t]{2}{*}{ Conditions } & \multicolumn{2}{|c|}{ Level of materiality } \\
\hline & Slightly material & Highly material \\
\hline Scope restrictions & $\begin{array}{l}\text { A qualified opinion except } \\
\text { for scope restrictions }\end{array}$ & $\begin{array}{l}\text { A disclaimer of opinion - } \\
\text { material scope restrictions }\end{array}$ \\
\hline $\begin{array}{l}\text { Non-compliance with the } \\
\text { accounting principles }\end{array}$ & $\begin{array}{l}\text { A qualified opinion except } \\
\text { for non-compliance with the } \\
\text { accounting principles }\end{array}$ & $\begin{array}{l}\text { An adverse opinion - material } \\
\text { non-compliance with the } \\
\text { accounting principles }\end{array}$ \\
\hline Unfair representation & $\begin{array}{l}\text { A qualified opinion except } \\
\text { for unfair representation }\end{array}$ & $\begin{array}{c}\text { An adverse opinion - material } \\
\text { unfair representation }\end{array}$ \\
\hline Going-concern uncertainties & $\begin{array}{l}\text { A qualified opinion except } \\
\text { for going-concern } \\
\text { uncertainties }\end{array}$ & $\begin{array}{l}\text { An adverse opinion - material } \\
\text { going-concern uncertainties }\end{array}$ \\
\hline $\begin{array}{l}\text { The auditor is not } \\
\text { independent }\end{array}$ & \multicolumn{2}{|c|}{ A disclaimer of opinion - the auditor is not independent } \\
\hline Multiple uncertainties & \multicolumn{2}{|c|}{ A disclaimer of opinion - multiple uncertainties } \\
\hline
\end{tabular}

Source: Wahdan, 2006

\subsection{The submodels of MEX}

As, using flowcharts approach is an effective tool to improve the education (Wahdan, 2018) of assessing planning and performance materiality. The first conceptual model consists of 3 models which are (1) determining the 
appropriate threshold category, (2) selecting the appropriate benchmark, and (3) determining the threshold level. The result of the third sub-model comes from the interaction among other 6 sub-models (control risk evaluation, management integrity evaluation, probability of the existence of financial difficulties determination, user's adoption on the financial statements, using of financial statements for special purpose, and management lifestyle) in addition to 2 direct questions. In order to comply with COSO's (COSO, 2013), it's a must to take into account the components of internal controls and called them relations that interact with each other to get conclusion about the control risk as illustrated in Figure 3.

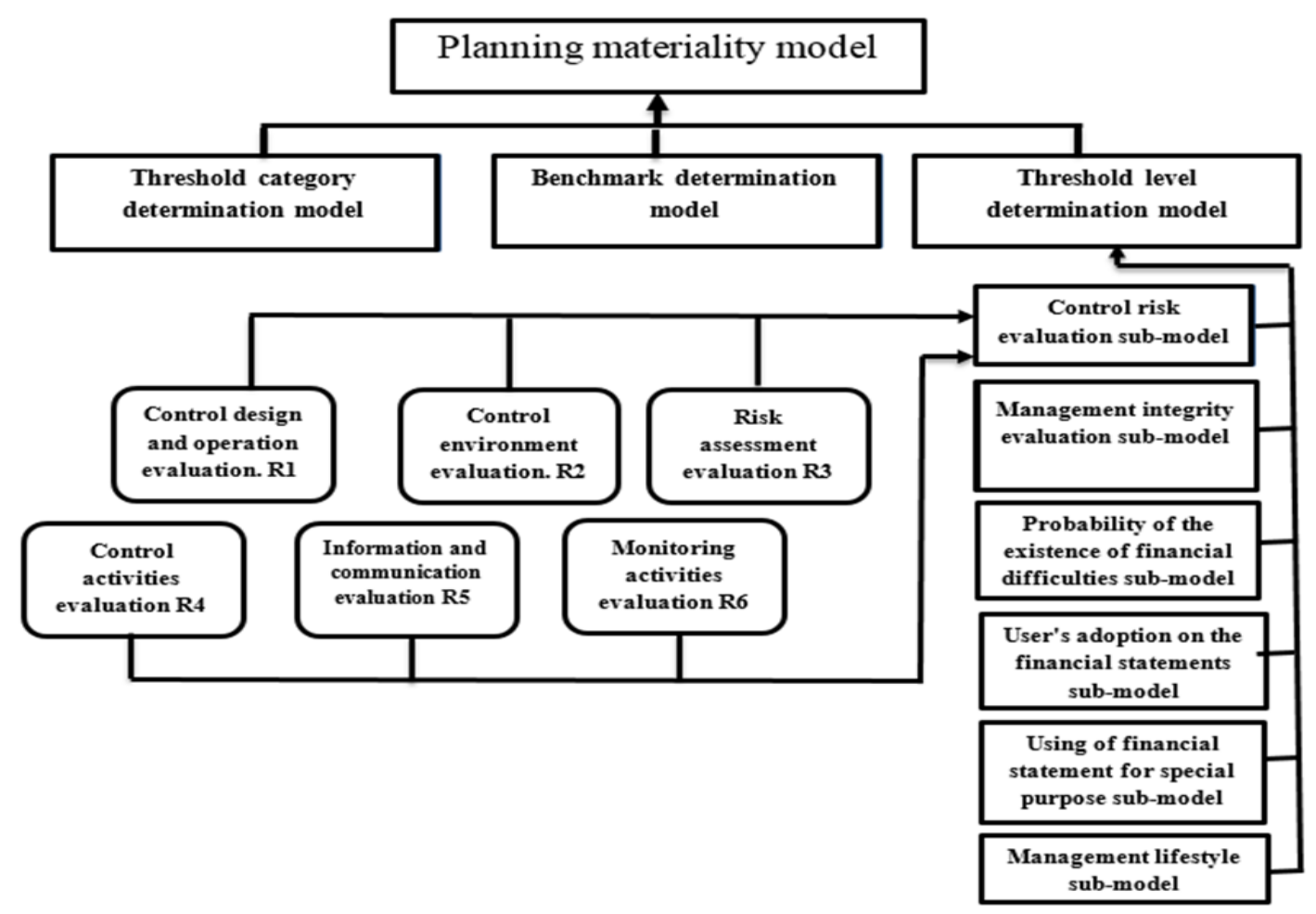

Figure 3: The conceptual model for MEX

The second conceptual model (performance materiality) consists of two models: (1) output of planning materiality model (result of the first conceptual model), and (2) performance materiality threshold level.

The following flowchart illustrate the process of determining threshold category, threshold level, benchmark, and performance materiality threshold level

1) Threshold category: From interviews with professional auditors in Egypt, we found that auditing firms classify the auditee into three categories: new entity, old entity-listed or entities in regulated industries, and old entity non-listed in unregulated industries. Figure 4 illustrates the threshold category determination. 
2) Threshold level: The input of threshold level determination sub-model comes from six relations (sub-models) which appear in Figure 3 and four direct questions about nature of misstatement, client commitment, auditorpast experience, and materiality level last year. Answers from both (relation, direct question) give the auditor reason to choose between the upper-end level and lower-end level. If the auditor decides that management integrity was questionable, he will reduce the threshold level to the lower end and this will affect the decision of determining the appropriate evidence to accumulate. Figure 5 demonstrates threshold level determination.

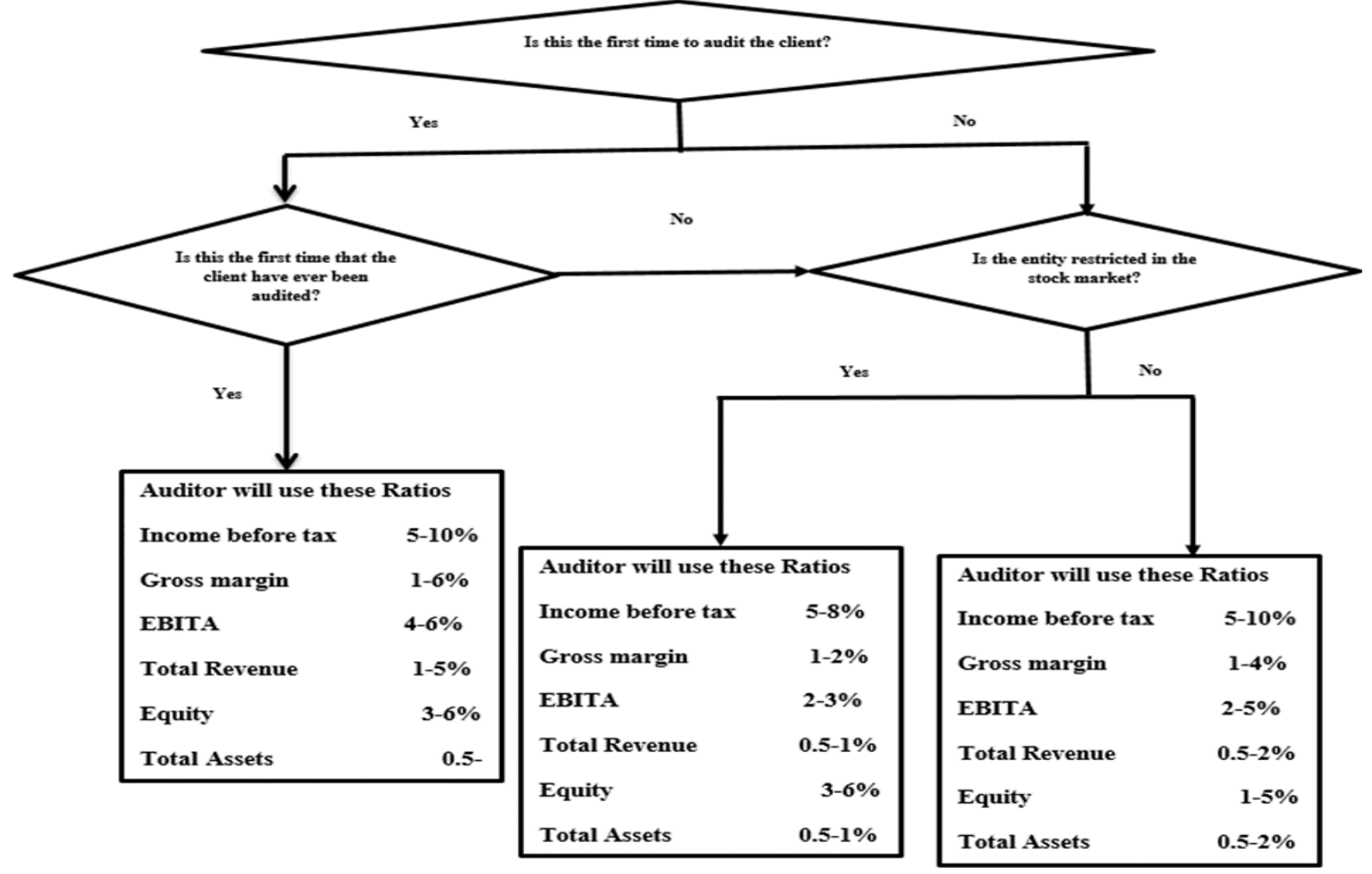

Figure 4: the threshold category determination

3) Benchmark determination: The choice of materiality benchmark is influenced by nature of the client (public or private), MEX will focus on private sector only and exclude financial institution, future plan of the client, needs of the user of financial statements, Income trend in the current year, and / or the entity is near to the break even or losses. Auditor may choose from several benchmarks such as gross margin, EBITA, total revenues, total assets, and equity. Figure 6 demonstrates base determination process.

4) Performance materiality threshold level: Auditors choose between two options, a percent of 50 OR 75 of planning materiality according to 
inherent risk level, control environment evaluation, and misstatements of the previous year. Figure 7 illustrate how to determine performance materiality threshold level.

Is there a high risk in management integrity? R (3-2)

No

Is there any probability to face financial difficulties? R (3-3)

No

Does user's adoption on the F.S high? R (3-4)

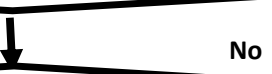

Are the F.S going to be used for special purpose? R (3-5)

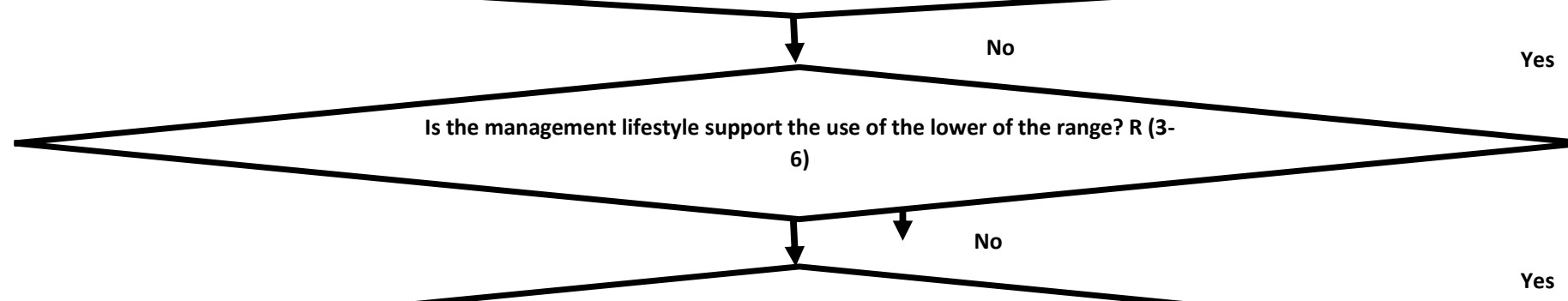

Do misstatements include errors which cannot be corrected in subsequent periods?

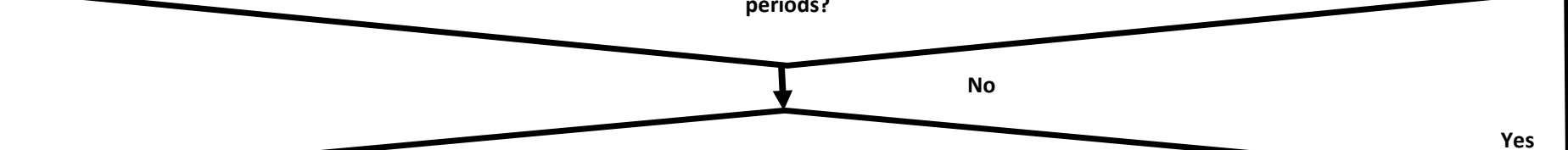

Does the client violate the terms of an agreement or contract which is used to get loan?

Does the auditor have a previous experience with auditee?

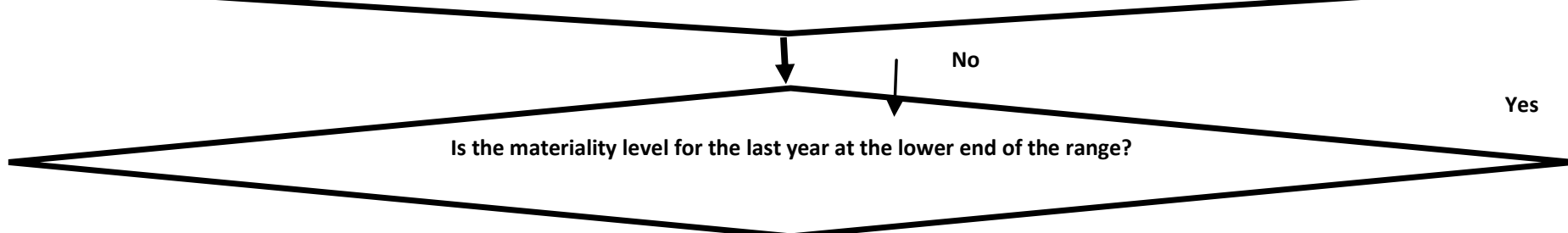

The auditor use the lower- end of the range

Figure 5: threshold level determination 


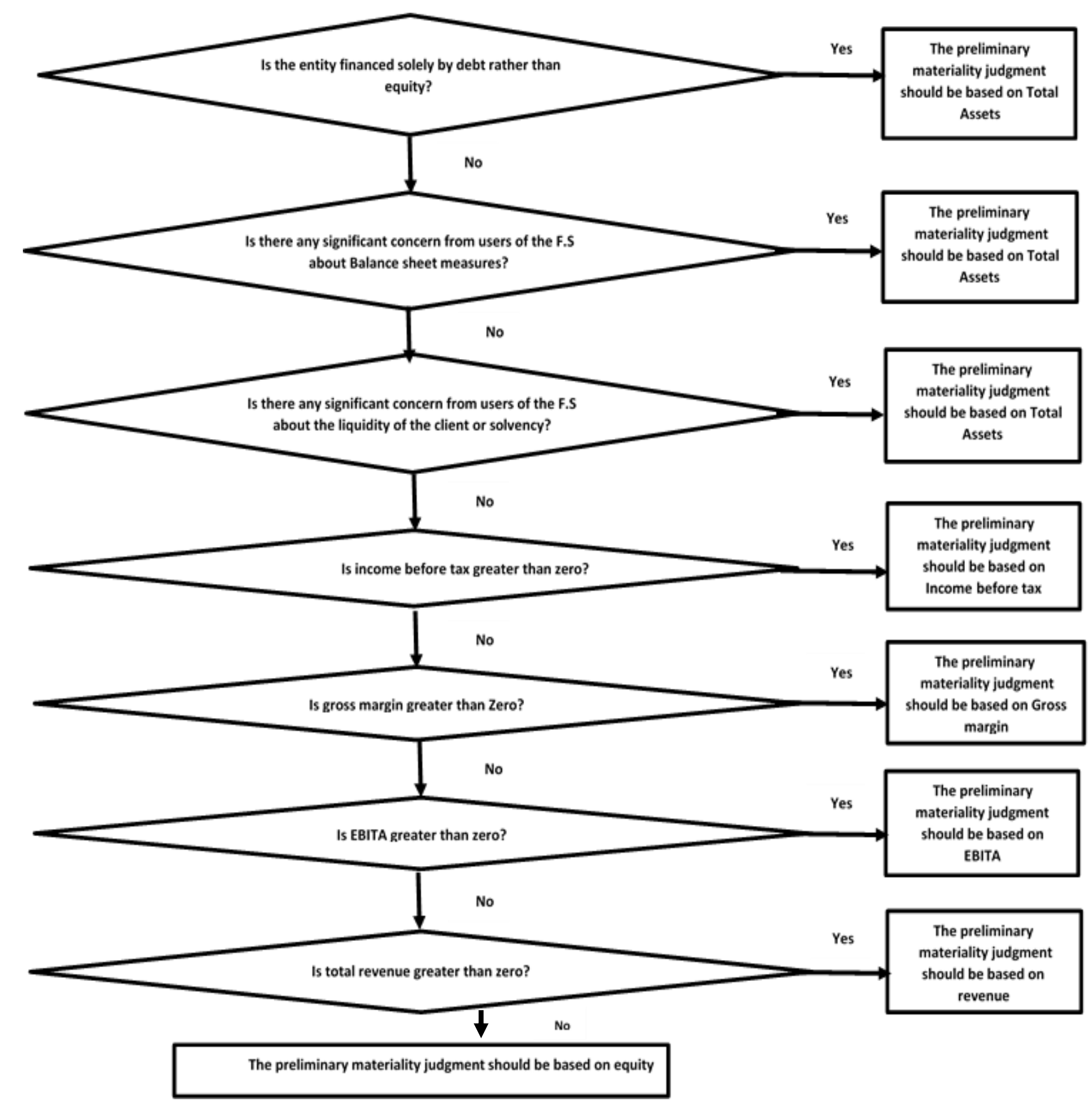

Figure 6: Materiality Base Determination

EBITA: Earnings before Income Tax and Amortization

\subsection{Knowledge representation}

The main challenge is how to model expertise. Extensible markup language (XML) was used in coding and storing data in order to represent knowledge in the database.

\subsection{Implementation of MEX}

Reasoning system is a software system that generates conclusions from available knowledge using logical techniques such as deduction and induction. 
C\# (C Sharpe) is a programming language that was used to build the reasoning system. The total number of MEX's concepts is 72 concepts and the total number of rules is 744 rules. User can find MEX on the desktop as MEX shortcut. If he makes double click on it, he will find the start page of the software that defines the software and how it works as illustrated in Figure 8. When clicking on start, a user interface will appear as in Figure 9.

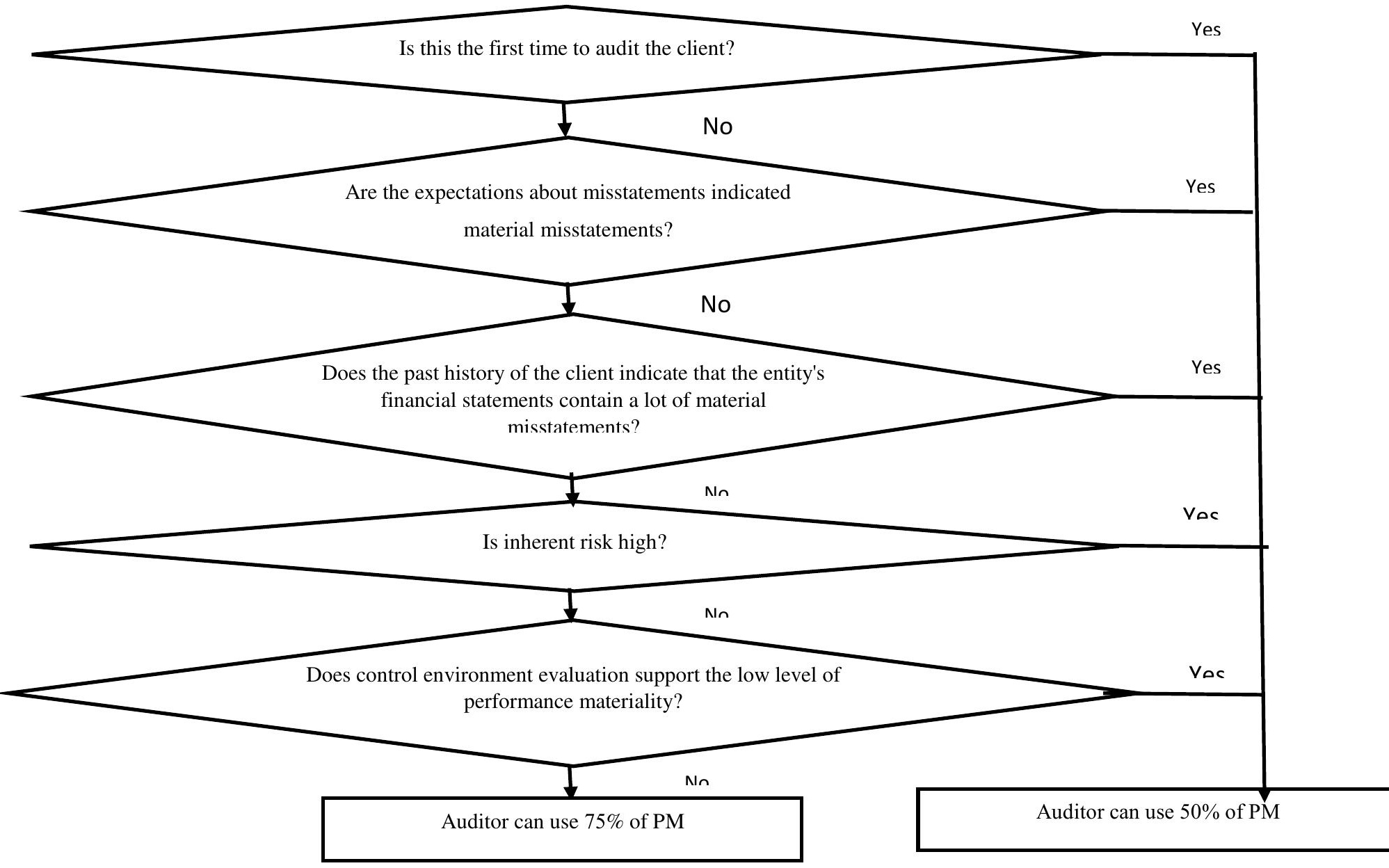

Figure 7: performance materiality threshold level sub-model 


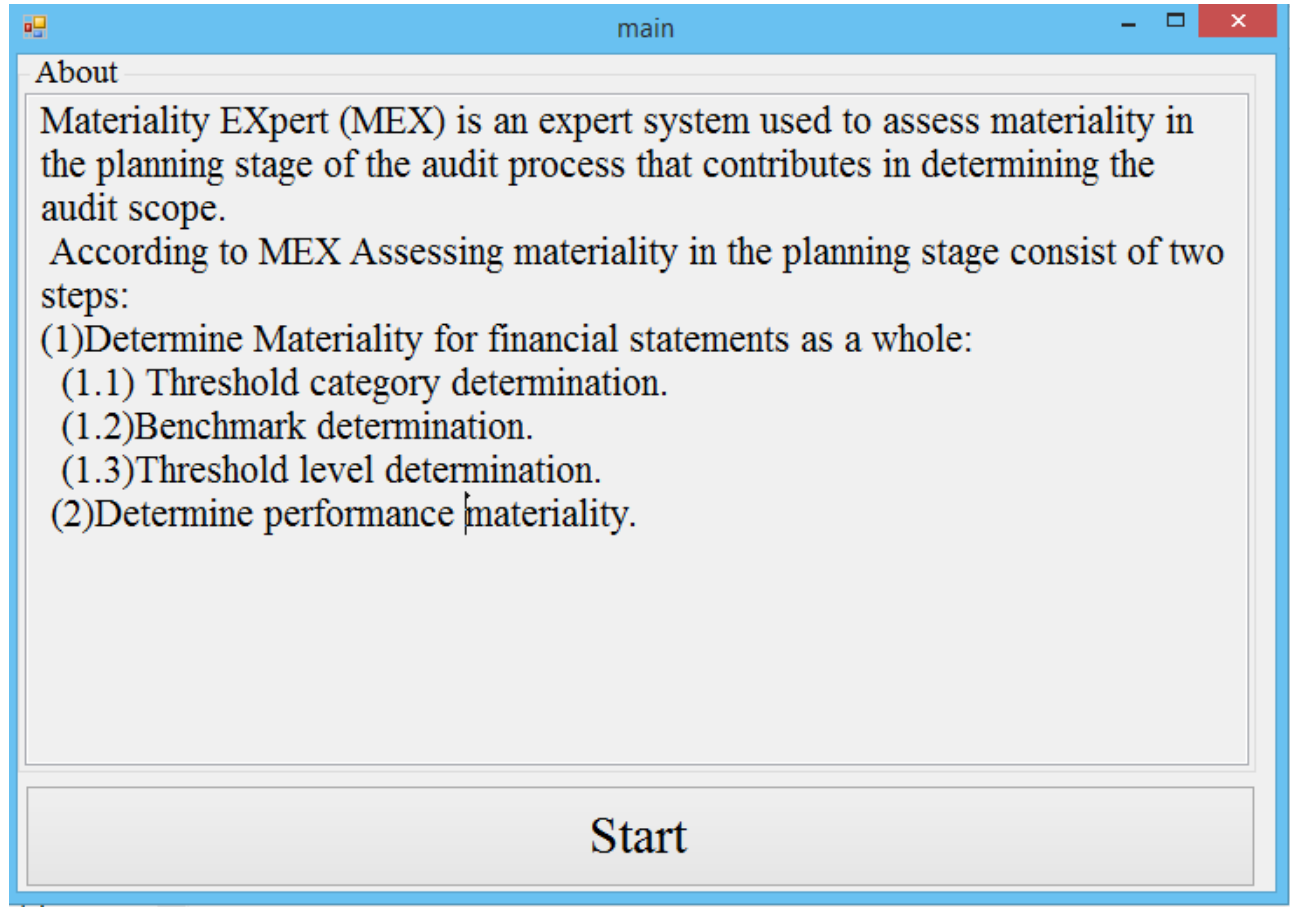

Figure 8: MEX start page

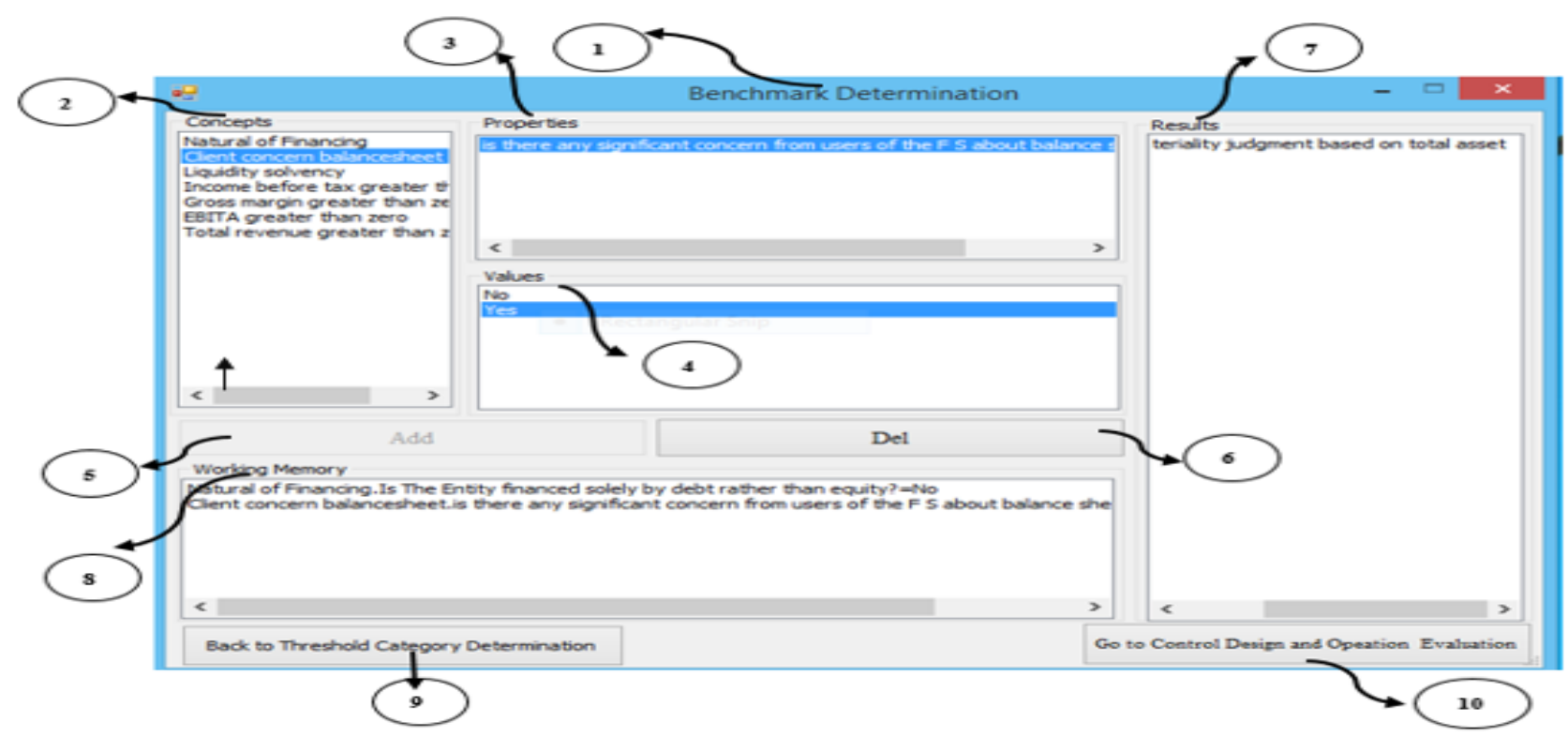

Figure 9: MEX's sheet screen

Where:

1. Model name

2. Concept to be evaluated

3. Properties represent the questions help in evaluating the concept (ex: internal control) or in making decision in this area (ex: which benchmark to use).

4. Values: when user clicks on specific concept and begin to answer to the questions in the property, he will find two options: yes or no.

5. Add button: used to ensure the chosen answer. 
6. Del button: is used when the user wants to delete answer of specific question.

7. Results: in this section, user will find all the expected choice but when he starts answering the questions, these choices will decrease up to be one. In this case the add button will be inactive.

8. Working memory: Store the questions that were answered in addition to its answers.

9. Back to threshold category determination button: to return to the previous screen in MEX

10. Go to control design and operation evaluation button: to go to the next screen in MEX. But this button is inactive until the user answered the questions required to give result in this screen.

\section{Evaluation of MEX}

According to central limit theorem, if sample size is greater than 30, it's allowed to use one sample t-test. After the auditors had used MEX, they were asked to answer questions formulated in the questionnaires in order to determine its effectiveness, efficiency, and acceptance in assessing materiality in the planning stage of the audit process. A five -point Likert scale was used in the questionnaire. The mean value of responses determines the level of the auditor's evaluation of the effectiveness, efficiency, and acceptance of MEX. As the mean values of less than 3 indicate that MEX failed in achieving the auditor's expectation. Also values more than 3 indicate that the proposed program meets the auditor's expectation. And values equal 3 indicate that MEX effectiveness, efficiency, and acceptance are medium.

\subsection{Effectiveness of MEX}

Effectiveness means the degree to which something is successful in producing a desired result (Dictionary, 2016).The simple definition of effectiveness is doing the right thing. In our study, effectiveness reflects the improvement in decision quality and accuracy when using MEX. Eleven statements in questionnaire are specified for testing the effectiveness of MEX: (1) as an auditing tool for assessing materiality in the planning stage in the audit process, and (2) as a training tool for auditors.

\subsubsection{MEX as an auditing tool}

In order to measure the effectiveness of MEX as an auditing tool for assessing materiality in the planning stage of the auditing process. Eight statements are used in order to test the soundness of logic and its potential usefulness. Table 6 indicates that the auditors strongly agree that MEX's logic reflects the professional performance and due care required when assessing materiality in 
the planning stage (Q. 1, Weighted mean $=4.264$, level of significance $=.000$ ) and MEX's knowledge and expertise is acceptable (Q. 8, 4.412, .000).

Table 6: Auditors' evaluation of MEX

\begin{tabular}{|c|c|c|c|c|c|}
\hline 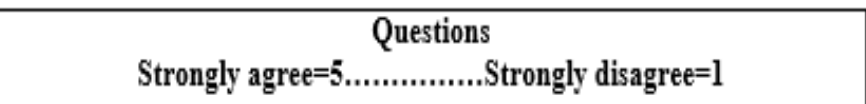 & $\begin{array}{c}\text { Mean } \\
\mathrm{n}=34\end{array}$ & $\begin{array}{l}\text { Std. } \\
\text { Dev. }\end{array}$ & $\begin{array}{l}\text { Std. } \\
\text { Err. }\end{array}$ & $\mathrm{T}$ & $\begin{array}{l}\text { Sig (2- } \\
\text { tailed) }\end{array}$ \\
\hline 1. MEX logic reflects professional performance and due care. & 4.2647 & .61835 & .10605 & 11.926 & .000 \\
\hline 2. MEX is appropriate and relevant in assessing materiality & 4.4118 & .65679 & .11264 & 12.534 & .000 \\
\hline $\begin{array}{l}\text { 3. MEX can assess materiality in the same manner as professionals can } \\
\text { do. }\end{array}$ & 4.3824 & .60376 & .10354 & 13.350 & .000 \\
\hline 4. MEX contributes in the auditor's commitment of auditing standards & 4.3529 & .59708 & .10240 & 13.212 & .000 \\
\hline $\begin{array}{l}\text { 5. MEX provides guidelines for auditors according to the required } \\
\text { procedures }\end{array}$ & 4.3824 & .60376 & .10354 & 13.350 & .000 \\
\hline 6. MEX's accuracy in assessing materiality in the planning stage. & 4.4412 & .61255 & .10505 & 13.719 & .000 \\
\hline 7. MEX's completeness as a program for assessing materiality & 4.4706 & .61473 & .10543 & 13.949 & .000 \\
\hline 8. MEX's knowledge base contains a complete knowledge and expertise. & 4.4118 & .60891 & .10443 & 13.519 & .000 \\
\hline 9. MEX is useful as a training tool for new auditors. & 4.2647 & .75111 & .12881 & 9.818 & .000 \\
\hline $\begin{array}{l}\text { 10. MEX helps auditor to understand how to assess materiality in the } \\
\text { planning stage of audit process. }\end{array}$ & 4.2941 & .75996 & .13033 & 9.929 & .000 \\
\hline $\begin{array}{l}\text { 11. MEX helps auditors in explaining in a better way the procedures } \\
\text { needed when assessing planning materiality }\end{array}$ & 4.3235 & .76755 & .13163 & 10.055 & .000 \\
\hline 12. MEX helps in reducing time needed for the task & 4.2647 & .70962 & .12170 & 10.392 & .000 \\
\hline 13. MEX helps in reducing the cost of audit process (auditor's fees) & 4.3235 & .76755 & .13163 & 10.055 & .000 \\
\hline 14. MEX is useful for auditors. & 4.1176 & .84440 & .14481 & 7.718 & .000 \\
\hline 15. MEX's logic is sound & 4.2353 & .78079 & .13390 & 9.225 & .000 \\
\hline 16. Phrasing of questions in MEX is simple and understandable & 4.3235 & .72699 & .12468 & 10.616 & .000 \\
\hline 17. MEX assessment can be trusted & 4.2353 & .60597 & .10392 & 11.887 & .000 \\
\hline $\begin{array}{l}\text { 18. Benchmark determination sub-model has a clear acceptance from } \\
\text { auditors. }\end{array}$ & 4.2353 & .49597 & .08506 & 14.523 & .000 \\
\hline 19. Control risk sub-model has a clear acceptance from auditors & 4.2647 & .56723 & .09728 & 13.001 & .000 \\
\hline $\begin{array}{l}\text { 20. Threshold determination sub-model has a clear acceptance from } \\
\text { auditors }\end{array}$ & 4.2647 & .56723 & .09728 & 13.001 & .000 \\
\hline $\begin{array}{l}\text { 21. Performance materiality determination sub-model has a clear } \\
\text { acceptance }\end{array}$ & 4.2647 & .56723 & .09728 & 13.001 & .000 \\
\hline $\begin{array}{l}\text { 22. The overall KBS gain a clear agreement from auditors about its } \\
\text { acceptance. }\end{array}$ & 4.3235 & .58881 & .10098 & 13.107 & .000 \\
\hline
\end{tabular}

Source: Statistical Analysis. Note: P-Values of all variables are less than .05; this means that each variable Mean of auditors' responses (which is more than 4) differs from number 3 (neutral) and all variables are significant at the level of confidence \% 95. So, there is an agreement on MEX efficiency, effectiveness, and acceptance as a tool to assess materiality. 
This evaluation reflects that MEX provides relevant information. Most auditors agreed on the usefulness of MEX in assessing planning materiality as it performs in the same manner, as the auditors would do (Q. 3, 4.38, .000). Auditors have evaluated MEX's reliability as good, reliability includes accuracy (Q. 6, 4.44), completeness (Q. 7, 4.47, .000), and relevant to the task of assessing planning materiality (Q. 2, 4.41, .000). Moreover, auditors agreed that MEX contributes in the auditor's commitment to auditing standards (ISA 320) (Question 4, 4.35, .000), and provides guidelines for auditors about the required procedures to follow when assessing materiality $(\mathrm{Q} .5,4.38, .000)$.

\subsubsection{MEX as a training tool}

In order to measure the effectiveness of MEX as a training tool for new auditors, we used (3) statements to illustrate the role of MEX in transferring the knowledge from professionals to novices. Table 6 shows that MEX is useful as a training tool for new auditors (Q. 9, 4.26, .000). In addition, the auditors agreed that MEX helps auditor understand how to assess materiality (Q.10, 4.29, .000). Also, MEX explains in a better way the procedures needed when assessing planning materiality $(\mathrm{Q} .11,4.32, .000)$.

\subsection{Efficiency of MEX}

Efficiency is doing the work with fewer resources (hours, dollars, etc.). Also it's the ratio of outputs to inputs (Wahdan, 2006; Madanhire \& Mbohwa, 2016). In this case, we measured efficiency of MEX by reducing the time required to perform the specific task (assess PM), and reducing the cost of audit process by reducing the numbers of organizational levels involved in these process. Table 6 shows that MEX improve the efficiency of the audit process by reducing the time required for assessing planning materiality $(\mathrm{Q}$. $12,4.2647, .000)$. Furthermore, there is a clear agreement between auditors that MEX reduces the cost of audit process (Q. 13, 4.32, .000).

\subsection{Acceptance}

Cambridge dictionary defines acceptance from the marketing view as it is the willingness of people to use a new product or service or to believe a new idea. The acceptance is a function of efficiency and effectiveness (Wahdan, 2006). Table 6 demonstrates how to evaluate MEX's acceptance. In this study we refer to acceptance as the professionals believe in the idea of this software as stated in the questionnaire: MEX is useful (Q. 14, 4.12, .000). The logic of MEX is sound and easy to follow (Q. 15, 4.24, .000). Moreover, phrasing of questions in MEX is simple and understandable (Q. 16, 4.32, .000). Finally, their confidence in MEX are (Questions 17, 18, 19, 20, 21, 22) with values equal $(4.24,4.24,4.26,4.26,4.26,4.32)$ respectively. 


\section{Conclusion and future research \\ 6.1. Conclusion and contributions}

This paper concerned with designing, implementing and evaluating a KBS called Materiality EXpert (MEX). MEX can assess planning materiality and performance materiality as professionals act. Knowledge used to build MEX is inducted from literature and from experienced auditors using questionnaire as well as unstructured and structured interviews. MEX was developed and consisted of two main conceptual models for assessing planning materiality and performance materiality. MEX was evaluated by 34 auditors from different audit firms in Egypt including international audit firms. The evaluation results acquired from experienced auditors in Egypt indicated that MEX successfully executes the task of assessing the level of planning materiality and performance materiality.

Moreover, the results of evaluation indicate that MEX is efficient as it can reduce the time required to perform the specific task. Moreover, it can reduce the cost of audit process by reducing the numbers of organizational levels involved in these processes. Therefore the use of MEX will improve the auditor's productivity. Furthermore, MEX is effective as an auditing tool for assessing planning materiality. MEX's logic reflects the professional performance and due care required when assessing materiality in the planning stage, MEX's knowledge and expertise is acceptable. The evaluation reflects that MEX provides relevant information. Most auditors agreed on the usefulness of MEX in assessing planning materiality as it performs in the same manner, as the auditors would do. Auditors have evaluated MEX's reliability as good, reliability includes accuracy, completeness, and relevant to the task of assessing planning materiality.

Furthermore, auditors agreed that MEX contributes to the auditor's commitment of auditing standards (ISA 320), and provides guidelines for auditors about the required procedures to follow when assessing materiality in the planning stage of the audit process. MEX is effective as a training tool. It helps to teach the novices how to assess planning materiality in a short time because MEX contains a lot of expertise and knowledge. In addition, auditors agreed that MEX helps in explaining in a better way the procedures needed when assessing planning materiality. Auditors agree about MEX's acceptance, as it is useful in the planning of the audit. The logic of MEX is sound and easy to follow. Therefore, their confidence in MEX is high.

This research contributes to the existing literature by adding and examining the acquisition and the use of technical knowledge in auditing especially in the planning stage. It provides an opportunity to improve the audit process. MEX will increase the likelihood that auditor's assessment of materiality complies 
with the international standards of auditing. Using MEX will reduce the inconsistencies of the personal judgments.

\subsection{Limitations and future research}

There are some limitations of the study as MEX was built to serve private sector in assessing planning materiality, and didn't contain regulations related to financial institution and public sector. Moreover, the answer of MEX questions either yes or no, it may affect the user's attitude when using MEX. Furthermore, auditor's biased towards using KBS. Any change in auditing standards after 2017 will affect the knowledge base of MEX. So, MEX knowledge should be continuously updated.

Moreover, we found difficulties in eliciting knowledge from experts, in addition to exploring probabilities on which rules are built. Based on the study limitations, many thoughts for future studies can be as follows: MEX might investigate regulations associated with public sectors and financial institution. Furthermore, MEX could be tested in training and educating new auditors, formatting excel sheet to MEX; it will be responsible for calculating PM and performance materiality through enabling MEX'S users to enter the value of the selected benchmark.

\section{Acknowledgement}

The authors would like to thank the reviewers and participants at 2018 International Conference on Computer Auditing (ICAEA 2018) in Dubai for their helpful feedback on earlier version of this manuscript.

\section{References}

Al-Sharairi, J.A. (2013). The Impact of internal Control to E-commerce Activities on the Quality of Accounting Information in the Bank operating in Jordan, The Journal of American Academy of business, Vol. 18, No. 2, pp: 202-209.

Arens, A.A., Elder, R.J. \& Beasley, M.S.(2014). Auditing and Assurance Services: An Integrated Approach, Global edition, Pearson, England.

Azzopardi, J. \& Baldacchino, P. (2009). The Concept of Audit Materiality and Attitudes towards Materiality Threshold Disclosure among Maltese Audit Practitioners. Bank of Valletta Review, No.40, Autumn.

Brennan, N. \& Gray, S.J. (2005). The Impact of Materiality: Accounting's Best Secret, Asian Academy of Management Journal of Accounting and Finance, Vol. 1, pp. 1-31.

Bukhsh, F. A. and Weigand, H. (2013). Towards a Formalization of Smart Auditing, Information Management Dep., Tilburg University, Tilburg, The Netherlands.

CAQ (2017). Research, Grants, RFPRAB Request for Proposals - Areas of Interest, Center for Audit Quality, Available at http:/www.TheCAQ.org.

Chen, H., Pany, K. \& Zhang, J. (2008). An Analysis of the Relationship between Accounting Restatements and Quantitative Benchmarks of Audit Planning Materiality, Review of Accounting and Finance, Vol. 7, No. 3, pp.236-251. 
Christensen, B. E., Eilifsen, A., Glover, S. M., \& Messier, W. F. (2018). The Effect of Materiality Disclosures on Investors' Decision Making, Available at: https://papers.ssrn.com/sol3/papers.cfm?abstract_id $=3096564$

Comunale, C.L. and Sexton, T.R. (2005). A Fuzzy Logic Approach to Assessing Materiality, Journal of Emerging Technologies in Accounting, Vol. 2, pp. 1-15.

COSO (The Committee of Sponsoring Organizations of the Treadway Commission). (2013). COSO Internal Control - Integrated Framework (2013), KPMG International, a Swiss Entity.

Council, F. R. (2017). Audit Quality Thematic Review Materiality. Available at: https://www.frc.org.uk/getattachment.

Curtis, M.B. \& Hayes, T., (2002). Materiality and Audit Adjustments, The CPA Journal, (April). Available at: www.nysscpa.org/cpajournal/2002/0402/dept/d046902.html/

Devale, A.B., Kulkarni, R.V. (2012). A Review of Expert System in Information System Audit, International Journal of Computer Science and Information Technologies, Vol. 3, pp. 5172-5175.

Dictionary, O., (2016). Framework. Retrieved August from Oxford Dictionaries, http://oxforddictionaries. Com/definition/ effectiveness.

Eilifsen, A., Messier, J., Glover, S. M. \& Prawitt, D. F. (2014). Auditing and Assurance Services, 3th Edition, McGraw-Hill Education.

Eilifsen, A., \& Messier, J., (2014). Materiality Guidance of the Major Public Accounting Firms. Auditing: A Journal of Practice \& Theory, Vol. 34, No.2, pp.3-26.

Emil, P. I., Ancuta, S. G. \& Timea, F. M. (2010). Qualitative Factors of Materiality - A Review of Empirical Study. Annales Universitatis Apulensis Series Oeconomica, Vol. 12, No. 1, P. 274.

Feng, J. (2017). Research on Internal Control of Accounting Information Systems in ERP Environment, advances in social science, Education and Humanities Research, 4th International Conference on Education, Management and Computing technology, Vol. 101, ICEMCT 2017.

Gist, W.E. and Shastri, T. (2003). Revisiting Materiality, The CPA Journal Online, (November).

Groomer, S.M. and Heintz, J.A. (1999). Using Flowcharts to Teach Audit Reports: An Update, Journal of Accounting Education, Vol. 17, pp. 391-405.

Gunawan, A. (2012). Information Access for SMEs in Indonesia: A Study on the Business Performance of Garment Manufacturers, PhD Thesis, Maastricht University, Maastricht, the Netherlands.

Houghton, K.A., Jubb, C., \& Kend, M. (2011). Materiality in the Context of Audit: the Real Expectations Gap, Managerial Auditing Journal, Vol. 26, No. 6, pp. 482-500.

IFAC (2009). International Standard on Auditing-Materiality in Planning and Performing an Audit, International Federation of Accountant, Available at http:/www.ifac.org.

Iskandar, T. M. (1996). Industry type: A Factor in Materiality Judgments and Risk Assessments. Managerial Auditing Journal, Vol. 11, No.3, pp. 4-10.

Juma'h, A. H. (2009). The Implications of Materiality Concept on Accounting Practices and Decision Making, Inter Metro Business Journal, Vol. 5, pp. 22-37, spring.

Laudon, K.C. \& Laudon, J.P. (2014). Management Information Systems: Managing the Digital Firms, 13Edition, Pearson, England.

Manita, R., Lahbari, H., \& Elommal, N. (2011). The Impact of Qualitative Factors on Ethical Judgments of Materiality: An Experimental Study with Auditors, International Journal of Business, Vo1. 6, No. 3. 
Madanhire, I., \& Mbohwa, C. (2016). Enterprise resource planning (ERP) in improving operational efficiency: Case study. Procedia CIRP, Vol. 40, pp: 225-229.

Messier, W.F. (2000). Auditing and Assurance services, Irwin McGraw-Hill, New York.

Montoya, D, J., Martínez, G. F. J., \& Fernández, L., A. (2010). Effective Use of Qualitative Materiality Factors: Evidence from Spain. Managerial Auditing Journal, Vol. 25, No. 5, pp.458-483.

MIA, (2012). Materiality in Planning and Performing Audit. Auditing and assurance, No. 2, April. Available at: http://www.mia.org.

Ndreca, P. (2013).Materiality-An Important Method and Techniques for the Financial Auditing, European Scientific Journal, Vol.9, pp.350-361.

O'Leary, D.E. (2003). Auditor Environmental Assessments, International Journal of Accounting Information Systems, Vol. 4, pp. 275-294.

PCAOB (2010), Auditing Standards Related to the Auditors Assessment of and Response to Risk, Available at: www.pcaobus.org, 1-291. Accessed on: 9/11/2017.

Pany, K., \& Wheeler, S. (1989). Materiality: An Inter-Industry Comparison of the Magnitude and Stabilities of Various Quantitative Measures. Accounting Horizons, Vol.3, No. 4, p. 71.

Park, J.J. (2009). Assessing the Materiality of Financial Misstatements, Journal of Corporation Law, University of Iowa,Vol. 34, pp.514-566.

Russ, M., Fineman, R., \& Jones, J. K. (2009). KARMA: Knowledge Assessment Review. Knowledge Management Strategies for Business Development, p.64. Available at: scholar.google.com/scholar? $q=$ Russ $+M$

Sagheb-Tehrani, M. (2009). A Conceptual Model of Knowledge Elicitation, In Proceedings of Conference on Information Systems Applied Study (CONISAR) 2009, Vol. 1542, pp. $1-7$.

Steinbart, P.J. (1987) The Construction of Rule-Based Expert System as a Method for Studying Materiality Judgments, The Accounting Review, Vol. LXII, No.1, pp. 97-116.

Vaassen, E.H. (1994). Auditors' Decision Processes in Audit Planning Stage Materiality Judgments, PH.D. Thesis, Faculty of Economics and Business Administration, Maastricht Universitythe Netherlands.

Wahdan, M. A. (2006). Automatic Formulation of the Auditor's Opinion. PH.D. Thesis, Maastricht University, Maastricht, the Netherland.

Wahdan, M.A. (2013). A Knowledge-Based System for Evaluating the Internal Controls over Financial Reporting, The First International Conference on Accounting and Auditing, Faculty of Commerce, Beni-Suef University.

Wahdan, M.A. (2018). Impact of a Practical Flowcharts Approach on Educating the Control Risk Assessment, Accounting and Finance Research, Vol. 7, No. 2.

Wahdan, M.A., Spronck, P., Ali, H. F., Vaassen, E., \& Herik, H.J. van den. (2005). Auditing in Egypt: A Study of Challenges, problems, and Possibility of an Automatic Formulation of the Auditor's report, The Proceeding of the Congress 14th IMDA, Tbilisi, Georgia, pp.293-300.

Wahdan, M.A., Spronck, P., Ali, H. F., Vaassen, E., \& Herik, H.J. van den. (2009). Computer Producing a 'Fair' Auditor's Report, The Proceeding of the Congress 18th IMDA, Granada, Spain, Vol. XIV, pp.91-98. 